\title{
Democratic Consolidation in Africa: The Ghanaian Paradigm
}

\author{
Popoola Michael Akin (Ph.D), Omosebi Fredrick Ade
}

\author{
Department of History and International Studies, Babcock University, Ilisan-Remo, Ogun State, Nigeria \\ Adventist development and Releif agency (ADRA), Seventh day Adventist Church Headquarters, Maryland, Lagos, Nigeria
}

\begin{abstract}
The 'Third Wave'of democracy resulted in transition galore in Africa. Authoritarian governments abandoned authoritarianism fora reconstructed political society which mirrors the institutions and processes of liberal democracy. What is strange however, is the fact that most of the countries that transited to democratic rule in the region about three decades ago are not making significant progress towards consolidating their hard earned democracy. Electoral violence and some other antidemocratic practices have made the mantra of good governance a mere rhetoric, and kept democracy perpetually nascent in most of the countries in the region. But worthy of note is the reference being made to Ghana, by some observers of African politics, as a beacon of democracy in Africa. The crux of this paper therefore is to attempt a critical evaluation of Ghanaian's democratic experience to determine the extent to which the country can be referred to as a consolidated democracy. Descriptive/qualitative method was used for data analysis. The paper discovered that Ghana indeed possesses some strikingly unique democratic experience which distinguish it from other African states. Although the countryis still struggling with some anti-democratic challenges like vote buying and executive recklessness, which if not properly addressed may erode any democratic gains recorded so far. Nevertheless, the impressive democratic credentials or the indices of democratic consolidation in the country as discovered by this research, can make one to conclude that Ghana is on the path of achieving democratic consolidation.
\end{abstract}

Keywords - consolidation, democracy, election, electoral violence, political party.

\section{INTRODUCTION}

Following the collapse of the Soviet Union in 1989, the United States of America and some western countries encouraged and supported the former authoritarian regimes, especially in Africa, to embark on transition programmes. Such states conducted elections into government offices, established civil rule to replace military autocracy and lay claim to liberal democracy. According to Manning (2005), between 1990 and 1995, about 34 countries in Africa organized some form of legislative elections in order to return to civil rule. Bratton and van de Walle (1997) too note that as at 1994 there was no single de jure one party state in Africa. This scenario heightened the optimism that the new democracies would soon stabilize and eventually get consolidated like the western democracies. But this optimism has remained a mirage. The reality on ground in most African countries indicates that little or no progress has been made toward democratic consolidation. A recent Freedom House Report revealed that more than two decades after the Third Wave of democratization, most countries in Africa can be rated either as Partly Free or Not Free, as regards democratization. They are still grappling with issues such ascoup d'état, socio-political conflict, bad governance, sit tight syndrome, electoral violence, corruption and many other anti-democratic behaviours which overshadowed electoral successes (Huntington, 1991)Thus, the fervor and enthusiasm which greeted transition programmes in Africa soon began to wane and optimism gave way for pessimism. Meanwhile, some political scholars have made a distinction between liberal and illiberal democracy or civil rule and democratic rule. They opine that the conduct of elections to fill political offices is not synonymous with established democracy or democratic consolidation. Democratic consolidation means stabilizing a new democracy, making it secure and preventing it from the threat of relapsing into authoritarianism. Sadly though, only a few countries in Africa can boast of some level of stability and democratic credentials which can put them on the path of democratic consolidation.

Ghana has been identified as one of the few countries in Africa where democracy has recorded some remarkable progress. Just like many other countries in Africa, Ghana, in time past, had its own experience of political instability, occasioned by incessant military incursion into politics. The country witnessed military interventions in 1966, 1972, 
1978, 1979, and 1982. But in 1993, it transited from military authoritarianism to democratic rule in what is commonly referred to as the country's Fourth Republic. However, some political observers lay claim to the fact that Ghana, since the beginning of the present Republic, has remained politically stable and made some surprisingly remarkable progress which put the country on the path of democratic consolidation. The crux of this study therefore is an attempts to analyse this claim vis-a vis the ingredients/elements of democratic consolidation so as to determine the strength of Ghanaians democracy.

\section{DECONSTRUCTINGDEMOCRATIC CONSOLIDATION}

Wolfgang (2006) posits that once a transition from authoritarian regime in a given country has reached a point where free, fair and competitive elections are held, democratic actors usually cannot afford to relax and enjoy the 'bounded uncertainty' of democratic rule. More often than not, regime threatening 'unbounded uncertainties' persist and the democrats fundamental concern usually shift from establishing democracy's core institutions to securing what they have achieved. For these actors, consolidating the new democracy is the next important task to achieve.

As a way of corroborating this, Kotze (2010) too opines that:-

once a state has abandoned authoritarianism and has reconstructed its political society to mirror the institutions and processes of liberal democracy, and has achieved institutional stability through processes and institutions such as elections, parliament and constitution, and has adopted commitment to values such as individualism, human rights, with a focus on the freedom of the individual, and commitment to procedural justice and the rule of law, such a state is a fully functioning or a consolidated democracy.

What democratic consolidation means remains a subject of debate and contention. Some scholars understand consolidation in probabilistic terms. This implies the expectation that a particular democracy is almost certain to survive indefinitely (Svolik 2008). Some other scholars focus their attention on how that expectation emerges by observing changes in attitude and institutions over time.

Democratic consolidation is defined as, 'making new and fragile democracy secure, extending its life expectancy beyond the short term and making it immune against the threat of possible reversal to authoritarianism (Bunbongkarn2007). In other words, democracy is consolidated when a weak, vulnerable and inefficient democracy is strengthened, made stable, vibrant, efficient, and accountable and the political actors can feel reasonably confident that democracy will persist in the near future. It is conceived as the process by which democracy becomes so broadly and profoundly legitimate among the political actors, at both the mass and elite levels, and accepted as the most right and appropriate for the society, better than any other alternative which the people couldenvisage. Svolik (2008) must have been echoing this when he said that democracy is consolidated when democracy is the only game in town.

In his own words, Myerson (2006) states that democracy is consolidated when democracy is made to work. When voters can keep candidates in line by the threat of a removal from office and when politicians believe that their chances of staying in office are greater when they behave in a principled rather than corrupt way.

The foregoing makes it abundantly clear that a consolidated democracy is synonymous with a robust and strengthened democratic system which can survive the crisis of transfer of power and still retains the basic fabric upon which democracy rests such as electoral process.

\section{INDICES OF DEMOCRATIC CONSOLIDATION AND THEGHANAIAN EXPERIENCE}

Scholars have identified certain elements or yard sticks for evaluating democratic consolidation. The performance of Ghanaians democracy would be reviewed against the background of the yardstick in order to determine the strength and robustness of the nation's democracy.

\subsection{BROAD ACCEPTANCE OF DEMOCRACY}

Linz and Stepan (1996) opine that a consolidated democracy is one in which the overwhelming majority of the people recognise democracy as the only game in town and believe that any political change must be within the parameters of democratic procedure. This corroborates Przeworski (1991) idea that democracy is consolidated when the major political players recognise sufficient common interest in establishing electoral procedures and subsequently see that their interest in keeping to the rules of the game over weights the cost to them. Perhaps this is why Ette (2012) posits that democratic consolidation is an attitudinal stance in which, even when a particular group is 
discontented with government's performance, they seek no other means to effect change or overthrow the political system except through democratic and institutionalized method.That is why Svolik (2008) evince the idea that democratic consolidation requires strong commitment to democracy, such as playing the game according to the rule by both the masses and political elite.

The Ghanaian masses have consistently demonstrated complete confidence in democracy and accepted it as the only legitimate way to rule. The political elite in the country too have learnt to abide by the regulations guiding the practice of democracy while election has been acknowledged as the only means of getting access to power. The two dominant political parties in the country:-the National Democratic Congress (NDC) and the New Patriotic Party (NPP) now accept the fact that when they loose an election, they have to wait for another general election in order to recapture power. Thus, the campaign for the next general elections in Ghana starts almost immediately after the announcement of election results Furthermore, the political sophistication demonstrated in Ghana after the sudden death of president Atta Mill in 2012 was another evidence of the love and resilience of Ghanaians for democracy. Barely six hours after the announcement of Atta Mill's death, the Vice President, John Dramani Mahama was sworn in as the new president,in accordance with the provision of Article 60 (6) of the 1992 constitution. The seamless transition was unparalleled in a continent where succession was always a tug of war like what Nigeria experienced shortly before and after the death of President MusaYar' Adua, when some cabals in Nigeria tried to prevent the Vice President from functioning as Acting President.

Furthermore, the way and manner the supporters of the NPP and NDC in Ghana were appeased to shun election violence during the 2008 presidential election debacle was an evidence of the level of political sophistication of the Ghanaian masses.Both the general elections and the run-off elections results were very close for the two major political parties in the nation. This brought about palpable tension which almost drove Ghana into a precipice. However, the supporters of the two parties demonstrated their love for democracy and the peace and unity which existed in their country as they listened to voice of reason and took the option of sheathing their swords. The scenario put Ghana on a parallel line with Kenya where a similar incidence almost turned the country into pieces in 2007 and 2008. The announcement of the incumbent president then, Mwai Kibaki as the winner of the December 2007 presidential election in Kenya resulted in an outburst of pent up angers which led to the death of about 800 people. Zimbabwe and Nigeria are also some of the African countries which are notorious for electoral violence. Therefore, the fact that Ghana was able to avert a looming electoral catastrophe in a continent riddledwith electoral violence made Majeed (2011) to conclude that 'Ghana has attained some degree of democratic consolidation'. No wander a survey conducted by Skanning across the countries in sub- Saharan Africa shows that the Ghanaians are the most satisfied with the growing level of their democracy in Africa

Nonetheless, some anti-democratic behaviours like vote buying or money politics are still common phenomenal in Ghana. Some politicians in the country believe that Parliamentary primaries are won by the highest bidders. For instance, an NDC parliamentary candidate for Jirapa Constituency once lamented that "primaries are killing our democracy because of the amount of money people spend to get elected'. The country's former President,John Mahama, was accused of vote buying through the distribution of free lap tops embossed with his portrait to Ghanaian students in 2012. His presentation of twelve brand new Toyota Land Cruiser vehicles to the National House of Chiefs wasalsofaulted. The opposition NPP claimed that the president's gesture was meant to woo the chiefs who were very influential in their respective domains to mobilize votes for the president and his party (Abdulai, 2014).This kind of political corruption is one of the things that can engenderslow death to democracy.

\subsection{NATIONAL COHESION}

According to Ette (2012) one of the ingredients of democratic consolidation is the ability of the majority of the people to keep pursuing the unity and peace of the country. This is a situation in which no group will engage in threat of secession from the state, or any other threat that can lead to democratic breakdown even in the face of imminent economic, social and political crisis. In other words, a very important element of democratic consolidation is a behavioral disposition of groups to constantly remain part of the country even in the face of obvious challenges.

Ghana, like many other countries in Africa is a multi-ethnic society. The ethnic groups in the country include; Ashanti/Akans, Mole-Dagbon, the Ewe, Ga-Adangbe, the Fante and several others. The country is also polarized by religion. The Southern part of the country, where the ruling NPP draws its major support is predominantly a Christian society, while Islam is the dominant religion in the Northern part which serves as the major political base of the NDC. 
Needless to say that these ethno-religious divisions sometimes play out in the country's politics. This notwithstanding, no identifiable group has made any attempt to secede from the country since the commencement of the Fourth Republic experience. It is interesting to know that most Ghanaians have demonstrated confidence in their government and cherished the peace and unity that prevail in their country which they are not ready to sacrifice on the altar of any political aggrandizement (Esi, 2012). As a means of preserving the peace, unity and tranquility which relatively exist in Ghana, leaders of faith based organizations and civil society groups regularly adopt various peacekeeping initiatives like peace walks, public lectures, songs, sermons and other programmes at Mosque, Churches, Market places and other public arena across the country to appeal to the people, particularly the youth to shun any act of violence that may threaten the unity of the country. They usually emphasise the fact that Ghanaians have more to gain staying together than when the country is fragmented. This peace effort is usually intensified across the country during electioneering campaign. This has to a large extent, helped to keep peace and unity in the country.

\subsection{ROBUST PARTY SYSTEM}

Institutionalized party system and stability of political competition is another ingredient of democratic consolidation. Mainwaring and Scully (1995) state that institutionalization facilitates democratic consolidation because it gives legitimacy to the political system by ensuring stability and predictability in governance. The political parties in Ghana have been institutionalized and have been able to perform their functions, such as political recruitment, interest aggregation, political education and provision of platform for aspirants effectively. Moreover, the stability of political competition and the alternation of power between the two dominant political parties in the country make them to be committed to democracy. Each of the two parties always has a high hope of winning elections and gaining control of the machinery of government. Elections are keenly contested because the two parties have almost equal strength. For instance, in the 2008 presidential run-off election, the NDC won 50.22 per cent while the NPP had 49.77 per cent. Similarly, the NDC got 50.70 of the total votes cast in 2012 presidential election while NPP got 47.74 of the total votes (Abdulai, 2014).

This spirit of sportsmanship is a sharp contrast to the experience of the Ugandans where Yuweri Museveni has personalized electoral process in order to perpetuate his administration of more than 30 years. The action of his government robs the people of Uganda of an electoral level playing ground. According to O'Donnell, Schmitter and Whitehead (1989), this kind of situation can only result into condensation or suffocation of electoral competition and erode the institutional pillar of democracy rather than guarantee democratic consolidation

Despite the robust party system however, the two major political parties in Ghana have been challenged for the way and manner they raised their campaign funds. There are wide spread allegations that the activities of the parties are bankrolled by individuals and organizations which have benefited from the contract awarded by the ruling party or those who anticipate rewards from the party if it wins the election. What made this allegation more popular is the failure of the two political parties to submit their audited financial records to the country's Electoral Commission as demanded by the constitution

Political observers have also noticed that the two major parties lack clear cut party ideology. The NDC leaned on social democratic ideology as it believes in pulling the marginalized, the disadvantaged and the poor into the mainstream of the socio-economic order. On the other hand, the NPP embraces Liberal Democratic principle of free economy which believes in the provision of the necessary enabling environment for the private sector to thrive. But a close observation of the programmes which the two parties have implemented at various times would reveal that The NDC has implemented some neoliberal economic policies like privatization just as the NPP has implemented some social intervention programmes like Youth Empowerment Scheme, Free maternal Health care, and Poverty alleviation Programmes (Osei, 2012). This lack of adherence to party ideology may affect the strength of political parties and by extension, democratic consolidation.

\subsection{TWO-TURN TEST (TTT)}

According to Huntington(1997), the 'Two-Turnover Test (TTT)' or transfer of power test is one of the strongest indices of determining the strength of a democracy. This implies that the country must have successfully alternated political power twice among competing political parties. In other words, if a government that was elected in a free and fair election is defeated in a subsequent election, it will accept the verdict and surrender power. This demonstrate the fact that in democracy, it is not only winning an election that matters, but losing in a contest and accepting the result as the popular will of the people. It also shows that the powerful players in electoral process and their supporters 
are prepared to respect the rule of the game and put it above the quest for continuation in office

Ghana, in the Fourth Republic has had seven successful general elections (1992, 1996, 2000, 2004, 2008, 2012 and 2016) including three democratic change of party in government. These took place in 2000, 2009 and 2017. Some scholars and researchers have commended J.J. Rawlings and John Kufour for not making efforts to manipulate the constitution to extend their stay in office beyond the two terms allowed by the constitution. President Rawlings completed the maximum of two terms stipulated by the constitution in 2001. Despite the fact that his anointed and preferred candidate,John Atta-Mill who was also his vice-President lost the presidential election, Rawlings still successfully handed over power to John Kufour of the opposition NPP who won the election. Similarly, in 2009, John Kufour respected the constitution as he handed power over to John Atta-Mill of the NDC party in spite of the fact that John Kufour's NPP lost the election by a very slim margin. As a matter of fact, John Kufour appealed to his party supporters who wanted to use the court to prevent the announcement of the result in 2008 that they should allow the Electoral Commission to do its job. In the same vein, in January 2017, President John Mahama who lost the December 2016 presidential elections handed power over peacefully to Nana AddoAkufo-Addoof the opposition NPP who won the election

All these are indications that democracy has been deepened in Ghana to the extent that the unconstitutional use of power of incumbency by public officials to perpetuate their stay in office is not acceptable. Rather incumbent party has learnt to bow to the will of the electorates. They are also indication of the fact that Ghanaians have cultivated a democratic political culture, in which there is a general consensus of a sense of interpersonal trust. This is the kind of trust that makes the ruling party relinquish political power willingly to the opposition party when defeated in an election without exercising any fear of political hounding. This is why the World Bank, in its 2009 World wide governance indicators, reported that Ghana has achieved significant progress on all dimension of governance assessed, including accountability, political stability and governance effectiveness which are elements of democratic consolidation.

This kind of political integrity demonstrated in Ghana is very rare in many African countries where 'sit-tight syndrome' is a common phenomenon. For instance, in 2007it was alleged that the former president of Nigeria, Chief Olusegun Obasanjo attempted to tinker with the constitution which allowed a maximum of two terms in order to make it accommodate three terms and pave the way for his 'Third Term' ambition. The unconfirmed report however said that the bid was stalled because it was not acceptable to the country's National Assembly. YahyaJammeh of the Gambia too did not want to end his 22 years rule in Gambia.He lost the December 2016 presidential election and congratulated his opponent and the winner of the election,AdamaBarow only toturn roundabout a week later to reject the result of the election, alleging irregularities and calling for a fresh elections. It took a concerted effort of the African Union to convince him to step down and give way for the swearing in of AdakaBarow. It appears, from all indications that democracy in Ghana has stepped beyond this level.

Regardless of this impressive democratic credential however,some political observers have faulted the enormous resources and executive power which the constitution places at the disposal of the Ghanaian president. This, according to them, may encourage abuse of power of incumbency, political patronage and breed corruption. In addition, the constitution accords unfettered power to the president to make most public sector appointments which he presents to the parliament for mere ratification. The President also has the power toappoint Ministers of States and Heads of Public Boards from among the parliamentmembers. Hence, the power to share political largesse with political accolades makes the president to enjoy political patronage. For example, the appointment of the members of parliament as Heads of Boards and as Ministers of states often deplete the parliament of some of its vibrant members and makes the parliament weak in carrying out some of its oversight functions, especially, the function of vetting the budget. This sometimes results into budget deficit and its attendant consequence (Essel, 2012) This is why KwasiPrempeh (2008) opines that the imperial presidency in Ghana dwarf the power of other state's institutions. This certainly portends danger for democratic consolidation.

\subsection{INTEGRITY OF ELECTORAL UMPIRE}

Democratic consolidation depends on the extent to which the primary political actors in a country agree on the institutions and rules that are necessary for the efficient and effective mediation of competing claims and how they are able to shape norms in line with the new political order. Therefore, for democratic consolidation to be achieved, the electoral commission must be seen to be impartial, autonomous, and the electorates must have implicit 
confidence in its judgement. Africa is notorious for electoral violence because the Electoral Umpires in many countries have allegedly compromised their independence and taken side with the ruling parties in election matters (Ademojubi, 2000).

The Ghanaians Electoral Commission has, over the years,proved to be an impartial and autonomous umpire by not subjecting itself to the manipulation of the government/party in power and it has worked very hard to maintain this credibility. Ghana has experienced alternation of power between the two most popular political parties in the country because of the credibility of the Electoral Commission. The Commission also works with political parties in the country through the 'Inter-Party Advisory Committee (IPAC)', to share ideas on electoral issues. Through this consultative process, the Commission and political parties have reached agreement on several controversial issues some of which include, the introduction of the 'lottery system' to determine the position of candidates on the ballot papers, the introduction of transparent ballot boxes and the representation of political parties at every stage of the collation and declaration of election result. These reforms have improved the transparency and integrity of the electoral process and consequently, the electorates in Ghana always demonstrate confidence in the Electoral Commission and accept its electoral verdict. Little wonderFrempong (2007) states that the Ghanaian Electoral Commission has gained a strong reputation as one of the most respected, competent, professional and independent electoral management bodies in Africa. Moreover, the Commission introduced the new biometric voter registration system during the preparation for the 2012 general elections and worked through religious bodies to educate their congregations on how the system functioned.

One can contrast the conduct of Ghana's Electoral Commission to what obtains in Nigeria where the people have little confidence in the electoral commission, the Independent National Electoral Commission and the election results it declares. This explains why every election result is always a subject of contestation and most of them end up in electoral tribunals. This made Momoh (2011) opines that election petitions litter everywhere in Nigeria. According to him, the Federal Court of Appeal received about 527 petitions after the 2003 general elections while about 1,200 appeals were filed in courts after the 2007 general elections. The reversal of several election victories by electoral tribunals is a confirmation of the level of fraud which plague elections in Nigeria. Zimbabwe, and
Uganda are other examples of Sub-Saharan African countries where the unacceptable conduct of Electoral Commissions usually lead to post-election violence.

Nevertheless, it is pertinent to know that the impressive conduct of Ghana's Electoral Commission, does not absolve the Electoral Commission of some challenges which may undermine democratic consolidation. One of the challenges is its inability to enforce the laws regulating the registration of political parties.Second, the Commission has been accused of some administrative laxity. The popular protest which greeted the shoddy manner in which the Commission created 45 new constituencies during the build-up to the 2012 elections was an evidence of its administrative weakness in election management. These kinds of lapses can make democratic consolidation unachievable.

\subsection{AUTONOMOUS AND IMPARTIAL JUDICIARY}

O' Donnell (2004) opines that one of the ingredients of democratic consolidation is the protection of the rule of law. This implies that a consolidated democracy must have a very strong and autonomous judiciary which is the custodian of the rule of law. The Judiciary must not be subjected to either the legislative or executive manipulation. The Ghanaian judiciary has demonstrated its autonomy and impartiality over the years through some politically sensitive landmarkjudgments which it has delivered, in some cases against the ruling party. The judiciary has also reviewed some actions of the state institutions which werenot in tandem with the constitution and declared them illegal. For instance, Hondari Okine, a Deputy Director of Ghana's immigration service during Rawlings administration challenged his dismissal by John Kufour's administration, claiming that it was politically motivated. The court delivered a judgement in his favour and ordered that he be restated to his position. More so, a former chief of staff to Jerry Rawlings, NanaAtoDadzie was charged and tried for financial impropriety by Kufour' administration, but the court discharged and acquitted him. Similarly, Kennedy Agyapong who was an NPP member of the parliament was tried for treason by Atta-Mill administration in 2013, but the court also discharged and acquitted him. (myjoyonline, June 2013). In addition, the Director and two officials of the Bureau of National Investigation (BNI) were charged for contempt of court by the Court of Appeal, following their refusal to obey the Human Right Court judgment which ordered the BNI to allow AsamoahBoateng, (a former Ghanaian Minister, who the BNI claimed was being investigated for various offence,) and his family to travel outside the country. These 
landmarkcases and many others, which were won against the governments of the day, made both the masses and the political actors to believe that they can approach the judiciary and get justice. Consequently, the constitutional paradigm in which the national laws and court systems are regarded as the only avenues for settling disputes between political and civil disputants is now ingrained in Ghanaians civic culture.

Unfortunately, the Ghanaian constitution permits the president to appoint the serving Judges of the highest court to serve on Public Boards. For instance, a Supreme court Judge, Justice Dr. Date-Bah was appointed by President John Mahama to serve as the Chairman of the Council of University of Ghana. Thisconstitutional provision makes some Judges to look up to the president for other appointments. One can say unequivocally that this development can compromise the independence of the judiciary especially, on cases which involve the executive arm of the government. We cannot over emphasise the fact that consolidation of democracy may be a mirage where the judiciary has lost its autonomy

\subsection{EXISTENCE OF A VIBRANT CIVIL SOCIETY}

Diamond (2008) states that democratic consolidation requires the existence of an autonomous organization or group like civil society, which could check the executive power by demanding for concessions, accountability and transparency from the government. Macedo (2011) too opines that the level of civil society participation and the quality of democracy are intrinsically related. He argues that policies are more effective and the quality of democracy is enhanced when solid relationship exist between the state and civil society.

In Ghana, the government hostility against civil society in the past years has changed to one of mutual understanding. The Ghanaian civil society has always pushed for participatory governance and decision making at different levels of government in Ghana. It has also fostered respect for diverse opinions, the rule of law, social justice, human rights, functional decentralised structures and broad based consultation and consensus-building (Apusiga, 2009).

The government is now convinced that its cooperation with civil society is for the good of the Ghanaians. Hence, their relationship has developed to the level that the government of Ghana now involves civil society, as an important actor in development process, in public policy debates, preparation of annual budget and some other developmental issues.(Gyimah-Boadi, 2008).This has strengthened Ghanaian democracy. The relationship between the duohas often attracted public appreciations of civil society by government officials as a viable partner in development. For instance, the former Ghanaian president, John Atta-Mill publicly acknowledged civil society organisations for their positive engagement to help Ghana fight corruption (Katsriku, 2010).As a matter of fact, President Barrack Obama of America justified his choice of Ghana as the first country he visited in sub-Saharan Africa as he said, 'My choice of destination was intended partly to highlight the critical role that sound governance and civil society play in promoting lasting development (African Development Research Series-Ghana, 2011).

\section{CONCLUSION}

This paper has examined the yard sticks for measuring the strength and vitality of a democracy which is synonymous to democratic consolidation. It has shown that to a very large extent, the political elite as well as the masses in Ghana have learnt to abide by the regulations guiding the practice of democracy. They accord the constitution a high regard as a sacrosanct document whose provisions are given utmost respect and generally regarded as the foundation of the country's democratic order. These impressive democratic credentials have distinguished Ghana from other countries in Africa. In other words, Ghana has been able to surmount some anti-democratic behaviours and bitter political rivalries which often plunge many Africa countries into electoral violence and make their democracy remain nascent. Therefore, given its commitment to the ideals of democracy one can say unequivocally that Ghana is a beacon of hope with regard to democratic consolidation in Africa.

Although, it is not yet eureka in Ghana, the country is still struggling with some anti-democratic practices such as executive recklessness, abuse of power by political elites, vote buying, money politics and campaign of calumny among others which the political elite in the country need to address. Nevertheless, when compared with other democracies in Africa, one may conclude that Ghana is experiencing a period of political freedom which makes it an example of working democracy that is setting the pace for other countries in Africa.

\section{REFERENCES}

[1] Abdulai, A. K. 2014. "Democratic Consolidation in Ghana"A Thesis Submitted to the Department of Political Studies, University of Saskatoon, Canada. 
[2] Ademojubi, S. 2000. "Elections in Africa: A Fading Shadow of Democracy?" International Political Science Review 21: 59-73

[3] African Development Research Series. (2011), audiencescapes.org/..Audience

Scapes\%20Ghana\%20Survey\%20Res. (Accessed 24/07/2017)

[4] Apusiga, A. (2009), "Civil Society Legitimation and Public Policy in Ghana". Institute of Democratic Governance (IDEG), Policy Research Series, No 5.

[5] .Beetham, D. (1994), "Conditions for Democratic Consolidation" in Review of African Political Economy, No.60. ROAPE Publications Ltd.

[6] Bratton, Michael and Nicolas van de Walle.1997. Democratic Experiments in Africa: Regime Transitions in Comparative Perspective. Cambridge: Cambridge University Press

[7] Bunbongkarn, S. (2007), The Role of Civil Society in Democratic Consolidation in Asia Tokyo: Centre for International Exchange.

[8] Diamond, L. (2008), "The Democratic Roll-back in Foreign Affairs". In Annals of the American Political and Social Sciences. Vol. 87(2

[9] Diamond, L. (1999), Developing Democracy: Towards Consolidation, Baltimore: John Hopkins University Press.

[10]Essel, I. (2012), President Mahama Presents 12 Vehicles to National House of Chiefs. http://politics.myjoyonline.com/pages/news/201211/97 150.php (Accessed 14/03/2017)

[11]Ette, M. (2012), "The Nigerian Press and the Challenges of Democratic Consolidation" https://docs.googlecom/viewer?a-v\&qcache:EaE4nttnsAsUJ:bedspsa.org (Accessed 14/06/2017)

[12] Frempong, K. Alexander (2007), "Constitution Making and Constitutional Rule in Ghana". A lecture Delivered at Golden Jubilee Colloquium, University of Ghana. 1-2 March,

[13] Huntington, S. 1991. "Democracy's Third Wave." Journal of Democracy 2 (2): 12-34

[14] Huntington, S. 1997. "After Twenty Years: The Future of the Third Wave" Journal of Democracy 8 (4): 3-12

[15] Katsriku, B. (2010), "The Paradox of Public ServiceCivil Society Collaboration inGhana", A Conference Paper delivered at CAPAM Africa Regional Conference, held from $17^{\text {th }}-19^{\text {th }}$ May.
[16] Kotze, J. S. (2010), Theory Building and Democracy: An Appraisal and Analysis of the Consolidation of Democracy Theory. A PhD Dissertation submitted to the Department of African Politics, University of South Africa

[17] Kwasi Prempeh, H. 2008. "Presidents Untamed." Journal of Democracy 19(2): 109-123

[18]Linz, J. and Stephan A. (1996), Problem of Democratic Transition and Consolidation in Southern Europe, South America and post Communist Europe, Baltimore: John Hopkins University Press.

[19] Macedo, J. P. (2011), Civil Society and the State: A Partnership for the Revitalisation of Democracy and Coherence Multilevel Global Governance, www.bertelsmannstiftung de (Accessed 10/02/2017)

[20] Majeed, M. (2011), "Civil Society and Democratic Consolidation in Africa: A Comparative Study of Ghana and Nigeria". A Research Paper submitted to the Department of Public Policy, Central European University, Budapest Hungary.

[21] Mainwaring, Scott and Timothy R. Scully.eds. 1995. Building Democratic Institutions: Party Systems in Latin America. Stanford, CA: Stanford University

[22] Manning, Carrie. 2005. "Assessing African Party Systems after the Third Wave." Party Politics 11 (6): 707-727

[23] Momoh, A. (2011), "Participatory Democracy and Political Accountability" A Lecture delivered at Wole Soyinka Center for Investigative Journalism, Lagos. July, 14 .

[24] Myjoyonline.com. June 20, 2013. MP Urges Parliament to Reject RLG Boreholes. http://edition.myjoyonline.com/pages/news/201306/10 8153.php (Accessed 28/06/ 2017)

[25] Myerson, R. (2006), "Federalism for Success of Democracy" in, Quarterly Journal of political Science. Vol.5 (3)

[26] O’ Donnell, G. (1998), cited in Schedler, P.. "Illusion about Consolidation" in Journal of democracy vol. 9, no2,

[27] Osei, A. 2012. Party-Voter Linkage in Africa: Ghana and Senegal in Comparative Perspectives. Konstanzi: Springer VS

[28] Prezeworski, A(1991), Democracy and the Market. Cambridge: Cambridge University press.

[29] Skanning, S. (2008), "Satisfaction with Democracy in Sub Sahara Africa: Assessing the Impact of System and Government Performance" A paper presented for MOPSA Conference, Tromso. August 6-9. 
[30] Svolik, M.(2008), "Learning to love Democracy: A

Theory of Democratic Consolidation"in

Journal of Democracy

[31] Whitehead, L (1989), "The Consolidation of Fragile Democracy"in A. P. Robert (ed)

[32] Democracy in the Americans, stopping the pendulum, New York: Holmes and Meter Wolfgang, B.(2006), Civil Society and Good Governance in Society in Transition. Vienna, European Training and Research Centre for Human Rights. 